\title{
FPS 1970 Uganda-Ethiopia Tour
}

In the fifth season of the Society's ORYX tours, it was reasonable to expect that features would have developed to distinguish them from the general run of wildlife tours; for they were among the first in this field of activity, which is having an increasingly important impact by persuading governments that conservation 'means business'. This expectation was fulfilled by the 1970 tour, in which an ORYX hallmark, certainly worth maintaining and developing, could be identified as 'the chance to get off the beaten track with enough time to do so to good purpose'.

Of course, it did not always work out quite as it should have doneventures on to new ground seldom do. But the pattern of longer stops and shorter journeys (though there were still three of over 300 miles) achieved a welcome reduction in packing and unpacking. With more opportunity to look round and probe hidden corners, that well-known 'indicator', the bird-list, topped 425 and included many recondite species; lovely ground orchids of the genus Eulophia rivalled rhino in their consumption of photographic film, and Ethiopia, in particular, yielded several mammals new to most members of the party-besides quantities of the tour's eponymous oryx.

That there was a residue of unsolved problems was perhaps only to be expected. Hidden corners tend to demand landrovers or rough forays on foot (the biting ants of the Bwamba forest were a good example of roughage), neither requirement being too easy to reconcile with a party of 24. We missed the blue-winged goose of the Ethiopian plateau and, most disappointingly, the Maramagambo and Budongo chimpanzees.

However, everyone had a share in some at least of the less usual experiences, besides enjoying the more traditional, of which the Kazinga channel and Nile launch trips, even the clustering of minibuses round a bored lion, can never really pall. The highlights were the visits to the Kidepo and Awash National Parks (both probably 'firsts' for a party of this size). Remote and unspoilt in appearance, if not altogether in fact, the potential of the first having only quite recently begun to be fully and expertly developed, that of the second barely beginning, they produced between them a superb variety of wildlife, even if glimpses of the Kidepo roan and cheetah and of the Awash greater and lesser kudu were tantalisingly brief.

Finally, this account of a journey which was, in fact, well endowed with incident as well as fauna and flora, would be even more incomplete without a grateful tribute to Wardens Wheater, Ziegler, Ross and Anstey and their staff, whose generous help and advice made the visits to their areas so much more rewarding, and also a special word of thanks to Alan King of Addis Ababa, whose kindness enabled a visit to the near-10,000 foot plateau overlooking the great gorge at Debra Libanos, with its bevies of Gelada baboons, thus ending the tour at a high level in more ways than one. 


\section{Another Wilderness Gone}

In the Cornell Laboratory of Ornithology's Newsletter, Tom J. Cade writes of a flight over the eastern part of Alaska's Arctic slope which he had not seen since 1963 :

'The changes on the ground were staggering. We passed over the erosion ... (which) resulted from the movement of a caterpillar tractor back and forth over the tundra. If this eyesore were an isolated case the situation would not be so bad . . . but similar ditches and tracks occur about every five to ten miles from the Canning River almost to the Colville, running in north-south lines from the Brooks Range to the coast. This unbelievably callous destruction of the terrain by geophysical crews working for the oil companies is unprecedented in the annals of Arctic explorations... Much of the winter road network will soon develop ... erosion which results from the melting of permafrost after the vegetative cover has been destroyed by motorised vehicles. In short, the wilderness I knew 20 years ago in northern Alaska is already a thing of the past. Except in some of the mountain fastnesses of the Brooks Range I doubt that one can find a roo-square mile plot of ground east of the Colville River-including the Arctic National Wildlife Range-that does not show some irreparable sign of man's unrelenting activities'.

\section{Arabian Oryx Births at Phoenix}

Three Arabian oryx births-two of them female-at Phoenix Zoo, in Arizona, in July and October last year and January this, have brought numbers in the World Herd up to $2 \mathrm{r}-$ from the eight originally deposited there by FPS, WWF, and the London Zoo in 1963/4. The two female calves both belong to FPS by the rules of the herd, bringing the Society's animals to II of the 2I. The new male calf born this year is the first second-generation animal; both its parents were born at Phoenix. In the wild the situation is less happy. Disturbing accounts of motorised hunts to shoot Arabian oryx in the desert continue to reach us and are being investigated. One source suggests as many as 17 were killed last winter.

\section{More Protection for Bears}

President Saragat of Italy has written to Prince Bernhard of the Netherlands, President of WWF, to say that the Abruzzi National Park, the degradation of which has been widely deplored, is to be extended by the addition of two largely uninhabited and wooded regions, totalling 9000 hectares, where bears are to be found: Mt Marsciano and Mt Godi. No tourist facilities will be allowed. In six months last year the Italian National Appeal of WWF paid out over $\oint_{1} 1 \mathrm{IO}$ in compensation to crop and stock owners in the Abruzzi for bear damage.

\section{Not only Turtles}

Dr Robert Schroeder's comment that 'the green turtle is the only organism that can turn sea grass into edible protein' (ORYX, December 1969, page I5I), has provoked the reply from Dr Colin Bertram that he 'forgets the Sirenians. Both the mammal and the reptile are doing the job, but the dugongs in particular are potentially more important in this respect even than the turtles'. Dr Bertram and his wife left in January for Ceylon where they are working on dugongs, aided by a grant from the FPS/WWF Revolving Fund. 